ROZ D Z I A E 6 .

\title{
ZAGADNIENIA ROZWIJANIA TURYSTYKI W STRATEGIACH ROZWOJU LOKALNEGO
}

\author{
Andrzej Piotr Wiatrak ${ }^{1}$
}

\section{Wstęp}

Dzisiaj o turystyce wiele się mówi i pisze, poruszając jej aspekty społeczne, środowiskowe, ekonomiczne i inne. To zainteresowanie wynika z roli, jaką turystyka spełnia zarówno w społeczeństwie, jak i w gospodarce. W związku z tym znajduje to odzwierciedlenie w polityce społeczno-ekonomicznej i to zarówno na szczeblu krajowym, jak i regionalnym, lokalnym. Wyrazem tego zainteresowania są przygotowane strategie rozwoju, w których w Polsce na każdym poziomie istnieje odwołanie do zagadnień turystycznych. Wszystkie strategie rozwoju lokalnego uwzględniają problematykę turystyczną, zwracając uwagę na ich istotną rolę jako czynnika także w zakresie zwiększenia dochodów przedsiębiorców i rolników ${ }^{2}$. Uwzględnić również należy możliwość łączenia działalności turystycznej z innymi formami aktywności: rolniczą,

\footnotetext{
${ }^{1}$ Prof. dr hab. Andrzej Piotr Wiatrak, Uniwersytet Warszawski.

${ }^{2}$ Por. A. Sadowski, Agroturystyka i ekoturystyka jako alternatywne metody zwiększania dochodów rolniczych, [w:] Podlasie - wizja rozwoju, A.F. Bocian. (red.), Fundacja Promocji Rozwoju Podlasia, Białystok 2004, s. 120 i następne.
} 
usługami zdrowotnymi, medycyną, agroturystyką, turystyką zdrowotną, ekoturystyką, ekoagroturystyką ${ }^{3}$.

Biorąc pod uwagę obecne zainteresowanie problematyką rozwoju turystyki, w niniejszym opracowaniu podjęto próbę przybliżenia istoty uwarunkowań rozwoju przedsięwzięć na szczeblu lokalnym przez strategie opracowane na tym poziomie. Cel rozdziału ma charakter poznawczy, a uzupełniająco - charakter aplikacyjny.

Materiał źródłowy, będący podstawą rozważań, stanowiły: literatura przedmiotu, strategie rozwoju lokalnego Lokalnej Grupy Działania „Razem dla Radomki” i własne przemyślenia autora. Wykorzystano metody przetwarzania danych, tj. analizę i syntezę.

\subsection{Istota strategii rozwoju lokalnego i miejsca w niej turystyki}

Strategia rozwoju lokalnego jest zbiorem decyzji i działań ukierunkowanych na realizację założonych celów i zadań społeczności danego obszaru (gminy, grupy gmin i powiatu) ${ }^{4}$. Odpowiada ona na pytanie: kto?, co?, kiedy?, gdzie?, jak?, za co?, po co? Określa szczegółowe cele działania i oczekiwane rezultaty. Strategia poprzedza działanie i jest ukierunkowana na przyszłość, przy czym przez rozpoznanie i przygotowanie pozwala zmniejszyć ryzyko i niepewność działań przedsiębiorców oraz określić sposoby ich finansowania (np. w zakresie rozwoju turystyki). Strategia zawiera przynajmniej następujące elementy5:

- podmioty rozwoju lokalnego, tj. władzy lokalnej, mieszkańców i przedsiębiorców;

3 Tamże, s. 120-131; A. Sadowski, M. Kozłowska-Burdziak, Przetwórstwo ziót i możliwości jego zwiększenia w województwie podlaskim, „Roczniki Naukowe Stowarzyszenia Ekonomistów Rolnictwa i Agrobiznesu” 2013, t. XV, z. 2, s. 325-329.

${ }^{4}$ Por. K. Obłój, Strategia organizacji, [w:] Zarządzanie. Tradycja i nowoczesność, J. Bogdanienko, W. Piotrowski (red.), Wydawnictwo PWE, Warszawa 2013, s. 105.

5 A.P. Wiatrak, Finansowe uwarunkowania przygotowania i realizacji strategii rozwoju lokalnego, „Nierówności Społeczne a Wzrost Gospodarczy” 2018, nr 56, s. 53-54. 
- cele przyjęte do realizacji oraz ich wielkość i hierarchię;

- narzędzia realizacji przyjętych celów, zadań i przedsięwzięć, w tym sposób ich finansowania;

- przyjęte rozwiązania w zakresie zarządzania i monitorowania strategii oraz jej ewaluacji.

Wymienione elementy tworzą system działań wzajemnie ze sobą powiązanych, od których zależy realizacja przyjętej strategii. Jeśli brakuje powiązania tych działań, to taka strategia staje się nierealna, nie w pełni wykonalna. Brak realności celów i działań strategii może występować zarówno na etapie jej przygotowania, jak i w czasie jej realizacji. W związku z tym na etapie planowania realnie należy podchodzić do możliwości danego obszaru i zasilania zewnętrznego, natomiast na etapie realizacji strategii należy zapewnić niezbędne środki jej wykonania. Ważna jest tutaj elastyczność działania, rozumiana nie tylko jako zmiana strategii, ale przede wszystkim jako zapewnienie środków na realizację strategii w warunkach zagrożenia jej wykonania. Oznacza to, że planując określone cele i działania należy zapewnić rezerwy na nieprzewidziane sytuacje, zagrożenia realizacji strategii, czy też wynikające ze wzrostu kosztów.

Cele rozwoju lokalnego dotyczą całokształtu funkcjonowania określonego obszaru. W związku z tym obejmują one różne zagadnienia, które ściśle są związane z danym obszarem, takie jak restrukturyzacja działalności podmiotów gospodarczych, wdrażanie innowacji, działania na rzecz poprawy kapitału intelektualnego, zagospodarowanie środowiska. Jednym z celów rozwoju lokalnego jest turystyka, obejmując różne jej rodzaje w zależności od posiadanych zasobów i walorów turystycznych oraz przyjętych kierunków rozwoju danego obszaru. Współcześnie turystykę traktuje się szeroko, jako „całokształt stosunków i zjawisk związanych z ruchem turystycznym”6. Planując rozwój turystyki, należy uwzględniać wszystkie te elementy, poczynając od dotychczasowego stanu rozwoju

${ }^{6}$ W. Kurek, M. Mika, Turystyka jako przedmiot badań naukowych, [w:] Turystyka, W. Kurek (red.), Wydawnictwo Naukowe PWN, Warszawa 2008, s. 13. 
turystyki, posiadanych walorów turystycznych i infrastruktury turystycznej i zasobów, które mogą być zaangażowane w jej dalszy rozwój, aż do określenia celów rozwoju turystyki i zadań oraz przedsięwzięć z nimi związanych.

Na ogół cele turystyczne są częścią strategii rozwoju danego obszaru, ale niektóre samorządy terytorialne przygotowują osobną strategię turystyki, która eksponuje walory turystyczne obszaru i przedsięwzięcia w zakresie infrastruktury turystycznej. Charakterystyczne jest to, że wszystkie gminy w swoich strategiach uwzględniają rozwój przedsięwzięć turystycznych, czasami niezależnie od posiadanych walorów turystycznych i doświadczeń w świadczeniu usług turystycznych. Przykładem tutaj mogą być przede wszystkim gminy wiejskie, w których zwraca się uwagę na rozwój przedsięwzięć agroturystycznych, chociaż nie zawsze mają taki charakter. Z kolei samorządy, które decydują się na samodzielną strategię turystyki, w większości posiadają doświadczenia w prowadzeniu działalności i rozwiniętą infrastrukturę, a także dysponują walorami turystycznymi, którymi mogą zainteresować klientów. Strategią rozwoju turystyki można określić program zamierzeń i kierunków działań władz danego obszaru w zakresie rozwoju turystyki.

Wykorzystanie turystyki jako czynnika rozwoju lokalnego jest możliwe - jak wynika z badań, gdy występuje ${ }^{7}$ :

- lider, który pobudza do działania; przy czym liderem może być osoba z władz lokalnych; jak i przedstawiciel społeczności lokalnej (np. stowarzyszenia turystycznego);

- mobilizacja społeczności lokalnej i jej integracja; zwłaszcza osób znaczących w tej społeczności;

- myśl strategiczna; określająca kierunki rozwoju turystyki i narzędzia jej urzeczywistniania oraz współpraca społeczności lokalnej w tym zakresie;

7 J. Kosmaczewska, Turystyka jako czynnik rozwoju obszarów wiejskich, Bogucki Wydawnictwo Naukowe, Poznań 2013, s. 25. 
- współpraca z otoczeniem; zwłaszcza z sąsiednimi gminami i powiatami;

- zasilanie zewnętrzne: środki finansowe i kapitał ludzki.

\subsection{Uwarunkowania rozwoju turystyki na szczeblu lokalnym}

Każdy obszar ma swoje drzewo celów i zadań, odpowiadające oczekiwaniom i zasobom, które mogą być przeznaczone na ich realizację. Od określenia misji oraz wyboru i hierarchizacji celów - opartych na istniejących uwarunkowaniach - zależy trafność wyborów strategicznych rozwoju turystyki oraz ich dostosowanie do studium uwarunkowań i kierunków przestrzennego zagospodarowania oraz miejscowego planu zagospodarowania przestrzennego. Dostosowanie to umożliwia wkomponowanie jej w integralny rozwój gospodarki danego obszaru oraz sprzyja zapewnieniu jego ładu przestrzennego (rysunek 6.1.). Rozpatrując ład przestrzenny, należy uwzględnić aktualną i projektowaną przestrzeń ekonomiczną oraz przestrzeń turystyczną - ich związki i charakter powiązania ${ }^{8}$.

Przygotowując strategię rozwoju turystyki lub celów rozwoju turystyki na szczeblu lokalnym, należy uwzględnić, jaki charakter ma realizowana polityka (np. dla trwałego rozwoju, ochrony środowiska, pomocy socjalnej) i jakie ma znaczenie dla prowadzenia działalności gospodarczej, w tym działalności turystycznej. I dalej - jak ta polityka wpływa na społeczeństwo, na jego zachowania produkcyjne i konsumpcyjne, na zagospodarowanie środowiska i inne. Zagadnienia te i ich powiązanie określają uwarunkowania zewnętrzne rozwoju turystyki, które mają wpływ na zachowania wewnętrzne (w ramach danego obszaru) oraz na zachowania produkcyjne, ekonomiczne i środowiskowe. Takie powiązanie w efekcie znajduje odzwierciedlenie w uwarunkowaniach wewnętrznych rozwoju turystyki.

${ }^{8}$ L. Przezbórska-Skobiej, Uwarunkowania rozwoju turystyki wiejskiej w Polsce. Analiza regionalna, subregionalna i lokalna, Wydawnictwo Uniwersytetu Przyrodniczego, Poznań 2016, s. 116 i następne. 
Rysunek 6.1. Strategia rozwoju turystyki na szczeblu lokalnym

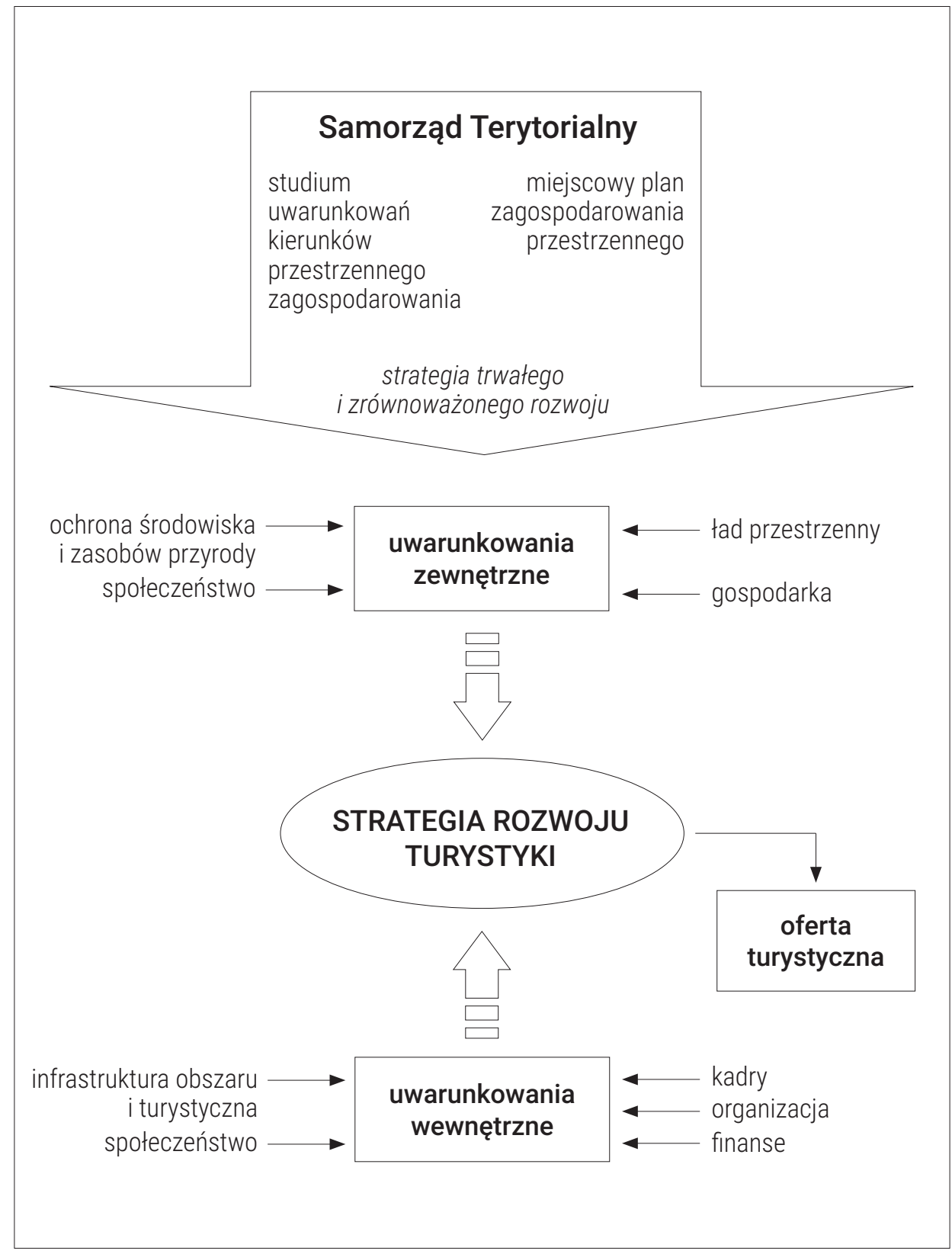

Źródło: opracowanie własne na podstawie: K. Kasprzak, B. Raszka, Polski ład przestrzenny szansą dla agroturystyki, „Przegląd Komunalny” 1998, dodatek nr 5, s. 12. 
Uwarunkowania wewnętrzne rozwoju turystyki są różnego rodzaju, a do najważniejszych należą (rysunek 6.1.):

- posiadane walory turystyczne oraz ich wielkość i struktura;

- infrastruktura danego obszaru (zwłaszcza infrastruktura techniczna);

- infrastruktura turystyczna;

- kapitał ludzki;

- posiadane środku finansowe; jak również możliwość ich pozyskiwania;

- sposób organizacji i zarządzania przedsięwzięciami turystycznymi.

Wyznaczając cele rozwoju turystyki należy dobrze zastanowić się nad ofertą turystyczną z punktu widzenia grup oczekiwanych turystów i motywów ich wyjazdów, w zależności od walorów turystycznych, jakie występują na danym obszarze i infrastruktury turystycznej. Walory turystyczne mają wpływ na charakter oferty turystycznej w zależności od ich rodzaju, a mianowicie walory ${ }^{9}$ :

- wypoczynkowe - tereny o walorach środowiska wypoczynkowego, sprzyjają rekreacji,

- krajoznawcze - obejmujące walory środowiska przyrodniczego, dobra kultury i współczesne osiągnięcia człowieka - sprzyjają przede wszystkim poznaniu danego obszaru,

- specjalistyczne - walory wędkarskie, myśliwskie, jeździeckie, żeglarskie i inne), które sprzyjają uprawianiu określonych typów turystyki specjalistycznej (np. wędkarstwu).

Określając cele rozwoju turystyki należy zastanowić się, które z tych walorów posiadamy, a jakie możemy posiadać w przyszłości. W gminach wiejskich należy zwrócić uwagę na ofertę turystyczną z rolniczych gospodarstw rodzinnych, która stanowi motyw przyjazdu turystów niezależnie od posiadanych walorów turystycznych. Zainteresowanie taką ofertą wynika z jej odmienności, charakteryzującej się mniejszą skalą, gościnnością, przestrzenią, kontaktem z przyrodą, swobodą poruszania,

\footnotetext{
${ }^{9}$ Z. Kruczek, Metodyka krajoznawstwa, Wydawnictwo AWF, Kraków 2000, s. 131.
} 
ciszą i innymi cechami turystyki alternatywnej. Są to ważne czynniki, o których należy pamiętać przy określaniu celów rozwoju turystyki w gminach wiejskich ${ }^{10}$. Ponadto należy uwzględnić, jaką mamy infrastrukturę turystyczną i czy sprzyja ona wykorzystaniu posiadanych walorów turystycznych. W odniesieniu do oceny przydatności i wielkości infrastruktury turystycznej należy zdecydować, czy warto podjąć inwestycje w tym zakresie oraz jakiego rodzaju mają one być.

W działaniach na rzecz turystyki powinno znaleźć się odniesienie do zasobów ludzkich, uczestniczących w przygotowaniu oferty turystycznej i obsłudze turystów. Uwzględnić tutaj należy m. in. kwalifikacje osób, zdolności kierownicze oraz predyspozycje osobowościowe. Wszystkie są ważne, ale w ostatecznym rozrachunku zależą od motywacji przygotowywania oferty pod względem jakości i jej polepszania oraz stworzenia przyjaznej atmosfery. Podkreślić należy, że chociaż podstawą strategii lokalnych są posiadane zasoby, to o ich uruchomieniu decyduje aktywność zarządzających jednostką terytorialną, ich postawa wyrażająca się w poszukiwaniu zmian i działań oraz merytoryczne podejście do przyjętych kierunków działań. Te cechy - obok kwalifikacji - są niezbędne w rozwoju turystyki, dlatego też dużą rolę powinien odgrywać system doradztwa i doskonalenia zawodowego.

I wreszcie dla realizacji przyjętej strategii należy mieć konkretne środki, odpowiadające przyjętym celom i kierunkom działań. Źródłami zasobów finansowych dla realizacji strategii samorządów terytorialnych są środki ${ }^{11}$ :

- samorządu terytorialnego,

- inwestorów lokalnych,

- inwestorów zewnętrznych.

${ }^{10}$ Por. M. Roman, Innowacyjność agroturystyki jako czynnik poprawy konkurencyjności turystycznej makroregionu Polski Wschodniej, Wydawnictwo SGGW, Warszawa 2018, s. 75 i nast.

11 A.P. Wiatrak, dz. cyt., s. 58-59. 
Analizując wymienione źródła finansowania rozwoju turystyki na szczeblu lokalnym należy uwzględnić, że ich wielkość zależy przede wszystkim od zasobów danego obszaru, jego wielkości, potencjału ekonomicznego, stopnia zagospodarowania i innych. Oznacza to, że zdolność uzyskiwania środków na rozwój przez jednostki samorządowe jest zróżnicowana. Uwzględnić też należy, że to są środki potencjalne, które dana jednostka samorządu terytorialnego nie zawsze uzyskuje (np. w okresie słabej koniunktury gospodarczej, czy klęsk żywiołowych). Podobnie jest ze środkami inwestorów lokalnych, które nie zawsze są wystarczające, zwłaszcza w gminach i powiatach o mniejszym potencjale ekonomicznym. W związku z tym istnieje potrzeba ich uzupełniania poprzez nakłanianie inwestorów zewnętrznych i uzyskiwanie pomocy finansowej na rozwijanie przedsięwzięć turystycznych. Pomoc taka w wielu gminach może być podstawą rozwoju turystyki lub częścią szerszych programów o charakterze ponadgminnym, finansowanych przez fundusze pomocowe (np. z funduszów strukturalnych Unii Europejskiej). Gmina i przedsiębiorcy, korzystając z tych środków, włączają się w istniejące programy, ale muszą pamiętać o własnym wkładzie - zgodnie z zasadą dodawalności środków. Natomiast pozyskiwanie inwestorów zewnętrznych jest możliwe w zależności od atrakcyjności wejścia na dany obszar, wyrażającej się w zwrocie funduszy przeznaczonych na rozwój i uzyskanie nadwyżki ekonomicznej.

Przygotowując ofertę turystyczną na szczeblu lokalnym należy odpowiedzieć sobie na różne pytania dotyczące prowadzenia tej działalności, m.in.:

- czy w przygotowaniu strategii i/lub celów rozwoju turystyki uczestniczyła społeczność lokalna oraz jaki był stopień jej uspołecznienia;

- czy infrastruktura danego obszaru umożliwia realizację funkcji turystycznej, czy też ogranicza, a jeśli ogranicza, to w jakim zakresie;

- jak są zagospodarowane walory turystyczne, czy istnieje ich ochrona i możliwość wykorzystania w przyszłości;

- jak wykorzystuje się infrastrukturę turystyczną, czy jest dostateczna;

- jakie są główne czynniki sukcesu w realizacji danych przedsięwzięć turystycznych; 
- jakie są bariery realizacji podjętych decyzji strategicznych i w jaki sposób można je ograniczać;

- czy podjęte decyzje strategiczne rozwoju turystyki mogą powodować naruszenie równowagi w sferze gospodarczej, społecznej i środowiskowej;

- w jaki sposób realizacja podjętych decyzji w zakresie rozwoju turystyki jest przygotowana na zmiany $w$ otoczeniu $\mathrm{i}$ inne.

Odpowiedzi na wymienione pytania pozwolą wskazać na uwarunkowania rozwoju turystyki, poznać ich współzależność, a w rezultacie zapewnić warunki do realizacji przyjętych celów, zadań i przedsięwzięć.

\subsection{Cele rozwoju turystyki na szczeblu lokalnym na przykładzie LGD „Razem dla Radomki”}

Gminy z obszaru Stowarzyszenia Lokalnej Grupy Działania „Razem dla Radomki” są obszarami rolniczymi, które stopniowo odchodzą od tradycyjnego rolnictwa na rzecz rolnictwa wyspecjalizowanego, produkującego na potrzeby miasta Radom (liczącego ponad 220 tys. mieszkańców), ale także na potrzeby aglomeracji warszawskiej i łódzkiej oraz miasta Kielce. Badane gminy spełniają wobec tych miast funkcje żywicielskie, nakierowane na zaspokajanie podstawowych potrzeb konsumenckich, ale także potrzeb turystycznych. Znajduje to odzwierciedlenie w przygotowanych strategiach rozwojowych. I tak pierwszy cel ogólny w strategii 2009-2015 ujęto następująco: „Podniesienie atrakcyjności turystycznej obszaru LGD poprzez wykorzystanie jego walorów przyrodniczych, kulturalnych i historycznych"12. Dla jego realizacji przewidziano $^{13}$ :

${ }^{12}$ Lokalna strategia rozwoju na lata 2009-2015 Lokalnej Grupy Działania „Razem dla Radomki”, Obszar działania: Jedlińsk. Przytyk, Przysucha, Wieniawa, Wolanów i Zakrzew 2009, s. 34; Strategia rozwoju produktu turystycznego obszaru Lokalnej Grupy Działania „Razem dla Radomki” na lata 2010-2015, Jedlińsk. Przytyk, Przysucha, Wieniawa, Wolanów i Zakrzew 2010, s. 69.

${ }^{13}$ Lokalna strategia... 2009-2015..., s. 34. 
1. Cele szczegółowe:

1.1. Stworzenie atrakcyjnej oferty turystycznej;

1.2. Ochrona dziedzictwa kulturowego i przyrodniczego;

1.3. Promocja lokalnych tradycji kulturalnych i przyrodniczych.

2. Przedsięwzięcia:

2.1. Dolina Rzeki Radomki atrakcją turystyczną i rekreacyjną;

2.2. Budowa spójnej oferty turystycznej mikroregionu LGD „Razem dla Radomki.

Także pozostałe cele ogólne pośrednio wiążą się z rozwijaniem funkcji turystycznej obszaru LGD, takie jak: wprowadzanie na rynek nowych produktów oraz podnoszenie jakości usług bazujących na lokalnych zasobach i produktach, w tym naturalnych surowcach i produktach z obszaru LGD, wykorzystanie dziedzictwa kulturowego i odnowa obszarów wiejskich czy też rozwój lokalnej aktywności i współpracy gospodarczej poprzez inicjowanie powstawania, rozwoju, przetwarzania, urządzania i porządkowania terenów zielonych, parków i innych miejsc wypoczynku. Działania te mają na celu zapewnienie ładu przestrzennego terenu LGD, powiązanego z dziedzictwem kulturowym, a także ze zróżnicowaniem struktury tych obszarów. „Obszar LGD »Razem dla Radomki« to przede wszystkim rzeka Radomka przebiegająca przez wszystkie gminy zrzeszone w LGD. Ponadto tereny obfitują w lasy, cieki i zbiorniki wodne: m.in. Puszcza Rozwadowska bogata w »skarby leśne« oraz »Domaniowskie Morze». Ponadto postacie Oskara Kolberga i Witolda Gombrowicza, obrzęd »Ścięcia Śmierci«, Ogólnopolskie Targi Papryki, to postacie, wydarzenia i atrakcje, które identyfikują obszar LGD w skali województwa i kraju"14.

W kolejnych latach 2016-2023 uwzględniono dotychczasowe działania Grupy LGD na rzecz turystyki, dlatego też położono inne akcenty na wspieranie turystyki, nie zwracając uwagi na rozwój bazy turystycznej, ale przede wszystkim na promocję obszarów, jego walorów i infrastruktury. Jeden z głównych celów sformułowano następująco: „Obszar LGD

${ }^{14}$ Strategia rozwoju produktu turystycznego..., s. 68. 
»Razem dla Radomki« atrakcyjny dla mieszkańców i turystów"15, a dla jego realizacji przyjęto następujące cele i działania ${ }^{16}$ :

1. Cel szczegółowy - wykorzystanie potencjału dla rozwoju oraz promocji obszaru LGD.

2. Działania:

2.1. Promocja dziedzictwa kulturowego i turystyki obszaru LGD;

2.2. Inwestycje w ogólnodostępną i niekomercyjną infrastrukturę turystyczną i rekreacyjną.

Wymienione cele i działania bezpośrednio oddziałują na funkcję turystyczną badanego LGD, ale należy też uwzględnić pośredni wpływ, wynikający z różnicowana i działalności obszaru oraz kreowania działań przedsiębiorczych w połączeniu z rozwijaniem kapitału ludzkiego i społecznego. Świadczyć o tym mogą m.in. działania dotyczące wsparcia przedsiębiorców, rolników, lokalnych organizacji i grup inicjatywnych w prowadzonej działalności (w tym turystycznej), wspieranie lokalnych artystów, rzemieślników i twórców ludowych oraz promowanie partnerstwa w wykorzystaniu nowo powstałej infrastruktury - partycypacyjne wykorzystanie obiektów infrastruktury publicznej ${ }^{17}$.

W rezultacie takie działania sprzyjają poprawie wizerunku tych terenów, a jednocześnie zwiększają ich atrakcyjność turystyczną. Podkreślić należy, że proponowane przedsięwzięcia turystyczne podkreślają walory przyrodnicze i turystyczne obszaru, które stają się podstawą przygotowania oferty turystycznej i jej promowania. Podstawą urzeczywistniania tych przedsięwzięć jest różnicowanie działalności gospodarczej w kierunkach pozarolniczych, takich jak ${ }^{18}$ :

${ }^{15}$ Lokalna strategia rozwoju Lokalnej Grupy Działania „Razem dla Radomki” na lata 2016-2023, Obszar działania: Jedlińsk. Przytyk, Przysucha, Wieniawa, Wolanów i Zakrzew 2016, s. 28-29.

16 Tamże.

17 Tamże, s. 48-49.

${ }^{18}$ Lokalna strategia... 2009-2015..., s. 34-40 oraz Lokalna strategia... 20162023..., s. 48-49. 
- rozwój usług turystycznych i okołoturystycznych (np. wypożyczania sprzętu rekreacyjnego); a w szczególności rozwój agroturystyki i jej różnych produktów;

- rozwój bazy noclegowej i gastronomicznej obszaru; z wykorzystaniem lokalnych produktów i dziedzictwa kulinarnego oraz produktów rolniczych;

- rozwój lokalnego rzemiosła i rękodzielnictwa oraz pamiątek;

- promocja rodzimych przedsiębiorców i produktów oraz ułatwienie zbytu produkcji; w tym promocja i komunikowanie się z klientami;

- promowanie innowacyjnych form działalności gospodarczej uwzględniających konieczność ochrony środowiska naturalnego i klimatu.

Realizacja poszczególnych działań łączy się z zagospodarowaniem istniejących obiektów oraz ich porządkowaniem i odtworzeniem dla nowych funkcji, ale także organizowaniem i rozwojem nowych przedsiębiorstw, zwykle mikroprzedsiębiorstw, np. hoteli, pensjonatów, kwater agroturystycznych, pól kempingowych, barów, restauracji i innych. Analizując poszczególne działania, należy zwrócić uwagę na odnowę istniejącej bazy i przystosowania jej do nowej działalności, w tym na rewitalizację budynków i ich przebudowę. Ponadto realizacja tych działań jest połączona z edukacją, szkoleniami i różnego rodzaju programami doradczymi rozwijającymi kompetencje zainteresowanych przedsiębiorców, jak i społeczności lokalnej, jej aktywności i działań na rzecz obszaru badanej LGD „Razem dla Radomki”.

\section{Podsumowanie}

Na szczeblu lokalnym jest miejsce dla turystyki, ale nie dla wszystkich gmin i powiatów w jednakowym stopniu. Przygotowując strategie rozwojowe należy uwzględniać różne uwarunkowania, poczynając od walorów turystycznych i infrastruktury turystycznej, poprzez narzędzia realizacji zwłaszcza środki finansowe i pomoc instytucjonalną (w tym edukacyjno-szkoleniową), a kończąc na popycie. Takie powiązania występowały 
w działalności Lokalnej Grupy Działania „Razem dla Radomki”, a analizowane strategie zostały starannie przygotowane, uwzględniając możliwości ich wdrożenia. Dotyczy to również środków finansowych, zwłaszcza w drugim okresie (2016-2023), ponieważ w pierwszym (2009-2015) zbyt ogólnie określono ich wielkość i przeznaczenie na poszczególne działania. Uwzględnić należy, że analizowane strategie zawierają działania o charakterze edukacyjnym (szkolenia i doradztwo), gdyż często dotyczą nowej działalności i wymagają poznania co najmniej jej podstaw. W rezultacie część zadań i działań zawartych w poszczególnych przedsięwzięciach została już zrealizowana, pozostałe są w trakcie. W konkluzji realizację podjętych przedsięwzięć oceniam pozytywnie. Wyraża się to w przebudowie struktury gospodarczej badanych gmin, zakładaniu nowych firm w działalności turystycznej, rozbudowie infrastruktury ogólnej i turystycznej, odnowie wsi i jej rewitalizacji, zwróceniu uwagi na sprawy środowiska i jego zagospodarowania i innych. Warto byłoby jednak szerzej zwrócić uwagę na turystykę świąteczną. 